\title{
The Influence of a Protein Fragment Extracted from Abalone Shell Green Layer on the Precipitation of Calcium Carbonate Polymorphs in Aqueous Media ${ }^{\dagger}$
}

\author{
Branka Njegić-Džakula, ${ }^{\text {a }}$ Michela Reggi, ${ }^{\mathrm{b}}$ Giuseppe Falini, ${ }^{\mathrm{b}}$ Igor Weber, ${ }^{\mathrm{c}}$ \\ Ljerka Brečević, ${ }^{\mathrm{a}, *}$ and Damir Kralj ${ }^{\mathrm{a}, *}$
}

\author{
${ }^{a}$ Laboratory for Precipitation Processes, Ruđer Bošković Institute, P. O. Box 180, HR-10002 Zagreb, Croatia \\ 'Dipartimento di Chimica “G. Ciamician”, Università di Bologna, via Selmi 2, I-40126 Bologna, Italy \\ ${ }^{c}$ Laboratory for Electron Microscopy, Ruđer Bošković Institute, P. O. Box 180, HR-10002 Zagreb, Croatia
}

\begin{abstract}
Many living organisms form mineral phases through biologically controlled processes, known as biomineralization. Thus created materials are composites of both, mineral and organic components. The shell of the gastropod mollusc red abalone (Haliotis rufescens) consists of calcite and aragonite layers, each of them containing characteristic biopolymers responsible for biomineralization. In this work, the effect of interstitial green sheet polypeptide, GP, extracted from the green layer of the mollusc red abalone shell, on the process of spontaneous precipitation of calcium carbonate polymorphs, was investigated. Three precipitation systems, in which the initial mineralogical composition of the precipitate was different, have been studied. Thus, in system (1) calcite appeared, in system (2) a mixture of calcite and vaterite was found, while in system (3), ASW, only aragonite precipitated. However, the precipitation kinetic measurements, X-ray diffraction, FT-IR spectroscopy, and light and scanning electron microscopy indicated that the addition of GP in the model systems caused the inhibition of precipitation and change of morphology of crystals as a consequence of GP adsorption on the crystal surfaces and its entrapment into the mineral structure. (doi: 10.5562/cca2197)
\end{abstract}

Keywords: calcium carbonate, calcite, aragonite, vaterite, green sheet polypeptide (GP)

\section{INTRODUCTION}

Many organisms are capable to construct a variety of mineral based materials, or biomaterials, by inducing crystallization and deposition of complex inorganic hierarchical structures. A precise control of crystal nucleation and growth, in which biological (macro)molecules play important roles by guiding the process, is essential for the properties of mineralized tissues formed. ${ }^{1}$ Although these biologically mediated processes, known as biomineralization, can occur in normal (e.g. bone, tooth enamel or shell of the mollusc) and in pathological circumstances (ectopic mineral deposits), the principles governing them are still not well understood. ${ }^{1-3}$ However, it is known that the formation of biominerals in organisms is controlled by different processes, sometimes synergic, like the regulation of concentrations of respective ions, formation of initial amorphous and other metastable precursor phases, and the presence of specific biomolecular additives. ${ }^{4-7}$
Calcium carbonate is among the most abundantly produced biominerals that may be formed biogenically in marine organisms, such as molluscs and crustaceans. It occurs in three anhydrous crystalline polymorphs (vaterite, aragonite and calcite) and three hydrated forms (calcium carbonate monohydrate, calcium carbonate hexahydrate and amorphous calcium carbonate), of which calcite is the most stable form under standard conditions. The role of metastable calcium carbonate modifications in the formation of crystalline polymorphs has recently been particularly emphasized. ${ }^{8-11}$ It is now well recognized and experimentally confirmed that many organisms, among them molluscs, ${ }^{12}$ use amorphous calcium carbonate as a transient (precursor) phase in the process of biomineral development. ${ }^{13,14}$ Such a pathway allows efficient transport of ions to the site of minerallization. ${ }^{8}$ It has been also suggested, ${ }^{15,16}$ that an amorphous phase can direct the formation of the specific polymorph into which it will transform. The mineralization control is mainly achieved by the

\footnotetext{
$\dagger$ This article belongs to the Special Issue devoted to the $85^{\text {th }}$ anniversary of Croatica Chemica Acta.

* Authors to whom correspondence should be addressed. (E-mails: damir.kralj@irb.hr, brecevic@irb.hr)
} 
involvement of organic matrix proteins, whose formation is directed in space and time at cellular level. ${ }^{17,18}$

A usual way of studying the organic matrix components is to extract them from the biomineral. The components, as agreed, are classified in two groups depending on their solubility in water solutions, ${ }^{1}$ although this distinction in some cases is not generally valid. ${ }^{19}$ In many cases the soluble fraction is characterized by the presence of acidic glycoproteins (rich in aspartic and glutamic acid residues) and the insoluble fraction is often formed by macromolecules able to build fibrous structures (chitin in mollusc shells, collagen in bones). The shell of the gastropod mollusc red abalone (Haliotis rufescens) consists of calcitic and aragonitic layers, each of them jointed together with characteristic biopolymers. The outer layer of the shell is made of red prismatic calcite and the inner layer, the nacre, is composed of aragonite tablets. Green organic sheets sandwiched between interstitial mineral heterolayers, which differ from nacre, are interspersed through the nacre at irregular intervals. ${ }^{20,21}$ The green sheet turned out to be a good model for the study of biomineralization processes of the molluscan shells, even if unique in the abalone shell. ${ }^{22}$ Indeed, it shares common features with the nacre organic matrix and the periostracum, and also has similarities to the myostracum. Moreover, it has been demonstrated that the green layer has nucleating properties for calcium carbonate either in vivo ${ }^{22}$ or in vitro. ${ }^{23}$

The green layer is highly insoluble and resistant to chemical and biological agents. ${ }^{22,23}$ After its alkaline digestion, water soluble protein fragment (GP) is obtained. The amino acidic composition of GP was found to be similar to the parent green layer and therefore suitable for using it as a soluble analogous of the nucleating green sheet. ${ }^{23}$ It is rich in acidic residues, aspartic and glutamic acid, in proline, tyrosyne and tyrosine derivates, that are actually responsible to GP unique fluorescent properties.

In this study, the effects of GP on the process of spontaneous precipitation of calcium carbonate polymorphs were correlated to its concentration and initial supersaturation in simple precipitation model systems, as well as in the system of artificial sea water (ASW). However, it should be kept on mind that the ionic composition of artificial sea water is similar to that of the extrapalial fluid present at the interface between mineral and soft tissue in mollusc shells. ${ }^{24}$

\section{EXPERIMENTAL}

\section{Materials and Methods}

Experiments were carried out in a thermostated doublewalled glass vessel of $20 \mathrm{~cm}^{3}$ capacity, at a constant temperature of $21{ }^{\circ} \mathrm{C}$. In order to precipitate different calcium carbonate polymorphs, three precipitation systems were investigated:

(1) Precipitation of calcium carbonate was initiated by pouring $10 \mathrm{~cm}^{3}$ of calcium chloride solution into $10 \mathrm{~cm}^{3}$ of sodium carbonate solution: the initial concentrations of the reactants were equal, $c_{\mathrm{i}}\left(\mathrm{Ca}^{2+}\right)=c_{\mathrm{i}}\left(\mathrm{CO}_{3}{ }^{2-}\right)$ $=1.0 \times 10^{-2} \mathrm{~mol} \mathrm{dm}{ }^{-3}$. The $\mathrm{CaCl}_{2}$ solution was prepared by appropriate dilution of a respective stock solution, while the $\mathrm{Na}_{2} \mathrm{CO}_{3}$ solution was freshly prepared by dissolving anhydrous sodium carbonate in water. ${ }^{25} \mathrm{An}$ appropriate amount of GP was added to the $\mathrm{Na}_{2} \mathrm{CO}_{3}$ solution and the GP concentrations used varied in the range $3 \mathrm{ppm} \leq c_{\mathrm{i}}(\mathrm{GP}) \leq 14 \mathrm{ppm}$. During the experiments the reaction vessel was tightly closed by a Teflon cover thus minimizing the exchange of carbon dioxide between the air and the reaction system, and enabling a strict control of supersaturation. The system was mechanically stirred at a constant rate.

(2) The procedure similar to system 1 was applied with the difference that the initial reactant concentrations were higher, $c_{\mathrm{i}}\left(\mathrm{Ca}^{2+}\right)=c_{\mathrm{i}}\left(\mathrm{CO}_{3}{ }^{2-}\right)=$ $2.0 \times 10^{-2} \mathrm{~mol} \mathrm{dm}^{-3}$, and the GP concentrations used varied in the range $3 \mathrm{ppm} \leq c_{\mathrm{i}}(\mathrm{GP}) \leq 10 \mathrm{ppm}$.

(3) In this system the precipitation was initiated in a solution that imitated the artificial sea water ${ }^{2}$ (ASW) or extrapallial solution of sea water mollusc shell. Identical to the previously described protocols, the volumes of reactants of $10 \mathrm{~cm}^{3}$ were used: the carbonate solution contained $c\left(\mathrm{Na}_{2} \mathrm{CO}_{3}\right)=5.0 \times 10^{-3} \mathrm{~mol} \mathrm{dm}^{-3}$, $c(\mathrm{NaCl})=3.198 \times 10^{-1} \mathrm{~mol} \mathrm{dm}^{-3}$ and $c\left(\mathrm{Na}_{2} \mathrm{SO}_{4}\right)=$ $5.11 \times 10^{-2} \mathrm{~mol} \mathrm{dm}^{-3}$, while the calcium solution was made up of $c\left(\mathrm{CaCl}_{2}\right)=9.3 \times 10^{-3} \mathrm{~mol} \mathrm{dm}{ }^{-3}, c\left(\mathrm{MgCl}_{2}\right)=$ $5.3 \times 10^{-2} \mathrm{~mol} \mathrm{dm}^{-3}$ and $c(\mathrm{KCl})=9.0 \times 10^{-3} \mathrm{~mol} \mathrm{dm}^{-3}$. GP was added into the carbonate solution and the precipitation was initiated by pouring the calcium containing solution into the carbonate solution. The concentrations of GP used in experiments varied in the range $3 \mathrm{ppm} \leq c_{\mathrm{i}}(\mathrm{GP}) \leq 20 \mathrm{ppm}$. In distinction from the previous systems, 1 and 2, the systems were continuously stirred at a constant rate by means of a Teflon-coated magnetic stirring bar.

In all systems the chemicals used to prepare reactant solutions, $\mathrm{CaCl}_{2}, \mathrm{Na}_{2} \mathrm{CO}_{3}, \mathrm{MgCl}_{2}, \mathrm{Na}_{2} \mathrm{SO}_{4}, \mathrm{KCl}$ and $\mathrm{NaCl}$, were analytical grade and the deionized water was of high quality (conductivity $<0.055 \mu \mathrm{S} \mathrm{cm}^{-1}$ ). The systems used as controls contained the same initial reactant concentrations and volumes, but without GP.

The progress of the precipitation process was followed by measuring $\mathrm{pH}$ of the solution during $70 \mathrm{~min}$ (systems 1 and 2) and $150 \mathrm{~min}$ (ASW system) of the process, using a combined glass-calomel electrode (GK 2401C) connected to a digital pH meter (PHM 290, Radiometer). The samples of precipitate used for the analyses were taken at the end of each experiment, 
when the total volume of suspension was filtered through a $0.22 \mu \mathrm{m}$ membrane filter. The precipitate was washed with small portions of water and dried at $50{ }^{\circ} \mathrm{C}$. The mineralogical composition of the dried samples was analyzed by FT-IR spectroscopy (FT-IR Mattson spectrometer, Genesis Series) using $\mathrm{KBr}$ pellets and by X-ray powder diffraction, XRD (Philips X'Celerator diffractometer). The diffraction intensities were measured in the angular range $10^{\circ} \leq 2 \theta \leq 60^{\circ}$ setting a step size $2 \theta=0.05^{\circ}$ and measuring time of $150 \mathrm{~s}$ per step. The calcium carbonate polymorphs were identified by using the FT-IR standards and according to the ICDD Powder Diffraction File. ${ }^{26}$ The concentration of total dissolved calcium was determined in the mother liquor by ion chromatography system (ICS-1100, Dionex) fitted with SC16 Analytical Column. The morphology of the crystals was observed by light microscopy (Leika microscope equipped with a digital camera) and by scanning electron microscopy (FEG SEM Hitachi 6400 and Phenom model G2). In some cases the samples used for the SEM observations were coated with gold. Confocal laser scanning microscopy was performed using a Leica TCS SP2 AOBS confocal microscope equipped with an HCX PL APO $\lambda$-Blue $63 \times / 1.4$ objective (Leica Microsystems). Fluorescence and transmission images were acquired simultaneously. For illumination, the $488 \mathrm{~nm}$ line from the Argon-ion gas laser was used and fluorescence was collected in the 500-590 nm range. Confocal fluorescence images were taken using the pinhole size of $114 \mu \mathrm{m}$ (1 Airy unit), corresponding to an optical section thickness of approximately $360 \mathrm{~nm}$ (FWHM).

Extraction of Green Layer Water Soluble Polypeptide (GP)

Shells of red abalones (Haliotis rufescens) were purchased from malacology shop. They were collected on the pacific coast, cleaned from the soft tissues and then stored at $-4{ }^{\circ} \mathrm{C}$. Nacre shell portion was mechanically separated, cleaned and decalcified in dilute acetic acid containing $0.1 \%$ sodium azide at $20{ }^{\circ} \mathrm{C}$. After decalcification, salts were removed from the remaining insoluble material by exhaustive washing with distilled water. The green interstitial polymer composite sheets were manually separated under the optical microscope. Extraction of GP was achieved by treatment of the green layer with $1.0 \mathrm{~mol} \mathrm{dm}^{-3} \mathrm{NaOH}$ for $24 \mathrm{~h}$. The solubilised material was dialysed against water (MWCO $3.5 \mathrm{kDa}$ ) and successively lyophilized.

\section{Treatment of Data}

On the basis of the measured $\mathrm{pH}$ and the known total initial concentrations of the precipitating components, the molar concentrations and activities of the ionic species present in solution at considerable amounts and at any moment of the precipitation process, were calculated. ${ }^{27}$ In the case of the precipitation systems 1 and 2, 11 ionic species were considered: $\mathrm{H}^{+}, \mathrm{OH}^{-}$, $\mathrm{CO}_{3}{ }^{2-}, \mathrm{HCO}_{3}{ }^{-}, \mathrm{NaCO}_{3}{ }^{-}, \mathrm{CaCO}_{3}{ }^{0}, \mathrm{CaHCO}_{3}{ }^{+}, \mathrm{CaOH}^{+}$, $\mathrm{Ca}^{2+}, \mathrm{Na}^{+}$and $\mathrm{Cl}^{-}$, while in the artificial sea water precipitation system, system 3 , the additional species were assumed to exist: $\mathrm{SO}_{4}{ }^{2-}, \mathrm{NaSO}_{4}{ }^{-}, \mathrm{CaSO}_{4}{ }^{0}$, $\mathrm{NaHCO}_{3}{ }^{0}, \mathrm{MgCO}_{3}{ }^{0}, \mathrm{MgSO}_{4}{ }^{0}, \mathrm{NaCl}^{0}, \mathrm{Mg}^{2+}, \mathrm{K}^{+}$, $\mathrm{MgCO}_{3}{ }^{0}, \mathrm{MgHCO}_{3}{ }^{+}, \mathrm{CaCl}^{+}, \mathrm{MgCl}^{+}$and $\mathrm{MgOH}^{+}$.

Detailed calculation procedure, as well as the corresponding equilibrium constants of ionic species can be found in literature..$^{25,27-31}$ The protein concentrations were always low in comparison to those of the calcium species and, consequently, calcium-protein complexation was not considered in the calculation procedure.

Supersaturation was expressed as saturation ratio, $S:$

$$
S=\left[a_{\mathrm{Ca}} a_{\mathrm{CO} 3} / K_{\mathrm{sp}}^{0}\right]^{1 / 2}
$$

where $a_{\mathrm{Ca}}$ is the activity of calcium ion, $a_{\mathrm{CO} 3}$ is the activity of carbonate ion, and $K_{\mathrm{sp}}{ }^{0}$ is the thermodynamic equilibrium constant of dissolution ("thermodynamic solubility product") of the corresponding calcium carbonate polymorph.

\section{RESULTS AND DISCUSSION}

Three sets of experiments were performed. In each set the initial supersaturation and/or solution composition were varied with the view of obtaining different polymorphic compositions of calcium carbonate precipitates. Thus, it was found that in the control precipitation system in which the initial concentrations of the reactants were $c_{\mathrm{i}}\left(\mathrm{Ca}^{2+}\right)=c_{\mathrm{i}}\left(\mathrm{CO}_{3}{ }^{2-}\right)=1.0 \times 10^{-2} \mathrm{~mol} \mathrm{dm}^{-3}$ (system 1) the precipitate isolated at the end of the experiment consisted entirely of calcite, while in the system $c_{\mathrm{i}}\left(\mathrm{Ca}^{2+}\right)=c_{\mathrm{i}}\left(\mathrm{CO}_{3}{ }^{2-}\right)=2.0 \times 10^{-2} \mathrm{~mol} \mathrm{dm}^{-3}$ (system 2) the precipitate consisted of a mixture of calcite and vaterite. Actually, the appearance of metastable polymorph vaterite was expected since its precipitation was a consequence of a higher initial supersaturation in this system. As found earlier, ${ }^{30}$ vaterite, if left in contact with the solution, would gradually transform to calcite as a consequence of the solution-mediated transformation process. In the control system in which the artificial sea water was used and the concentrations of reactants were $c\left(\mathrm{CO}_{3}{ }^{2-}\right)=5.0 \times 10^{-3} \mathrm{~mol} \mathrm{dm}^{-3}$ and $c\left(\mathrm{Ca}^{2+}\right)=9.3 \times 10^{-3} \mathrm{~mol} \mathrm{dm}^{-3}$ (system 3 ), ASW system, only aragonite was obtained. Aragonite is relatively stable polymorph especially when in contact with magnesium ions, which promote its nucleation and stabilize it in the solution. The mineralogical composition of precipitates was detected by both, XRD and FT-IR 


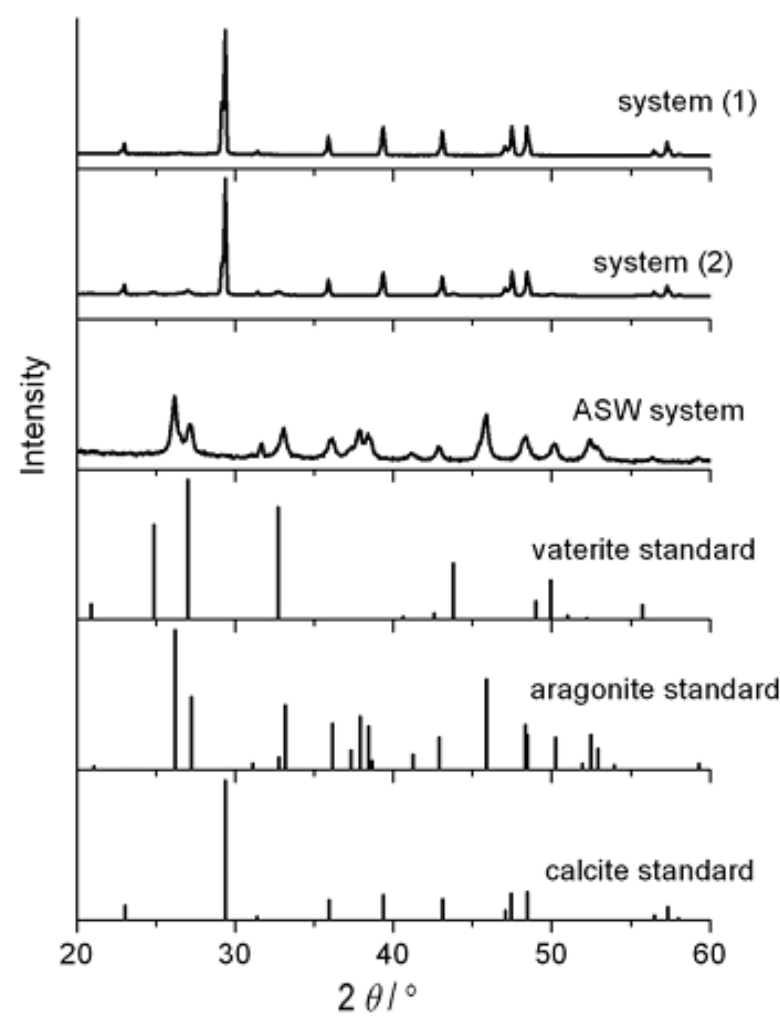

Figure 1. X-ray diffractograms of the calcium carbonate samples isolated from the precipitation model systems of different initial supersaturations and compositions: system 1: $c_{\mathrm{i}}\left(\mathrm{Ca}^{2+}\right)=c_{\mathrm{i}}\left(\mathrm{CO}_{3}{ }^{2-}\right)=1.0 \times 10^{-2} \mathrm{~mol} \mathrm{dm}{ }^{-3}$, system 2: $c_{\mathrm{i}}\left(\mathrm{Ca}^{2+}\right)$ $=c_{\mathrm{i}}\left(\mathrm{CO}_{3}{ }^{2-}\right)=2.0 \times 10^{-2} \mathrm{~mol} \mathrm{dm}^{-3}$ and system 3 (artificial sea water, ASW). The XRD standards are also shown.

spectroscopy. Figure 1 shows the XRD patterns of the samples isolated from all three control systems, which are compared with the XRD patterns of the respective standards of calcium carbonate polymorphs. It is evident that in system 1 only diffraction peaks of calcite were obtained, while in system 2 diffraction patterns of both calcite and vaterite were found. In the case of ASW precipitation system, diffraction peaks distinctive for aragonite, as well as two additional peaks at $2 \theta=31.8^{\circ}$ and $2 \theta=56.4^{\circ}$, could be seen. These additional peaks correspond to $\mathrm{NaCl}$, which remained in the precipitate as contamination after separation of aragonite from the suspension and drying the samples.

The mineralogical composition of the precipitates, which were isolated from the systems in which the green layer polypeptide (GP) was added, showed no significant difference from the respective control systems, regardless the GP concentrations used. In the same way as was the case of the control system, the samples of precipitate were isolated after the apparent termination of the growth process.

The kinetics of spontaneous precipitation, in the systems containing different amounts of GP and in the respective control systems, was followed by measuring the solution $\mathrm{pH}$. Figure 2 shows the progress curves of precipitation processes, $S_{\mathrm{c}}$ versus time, recorded in the presence of different GP concentrations. The respective $\mathrm{pH}$ versus time curves, from which the supersaturations, $S_{\mathrm{c}}$, were calculated, are shown in insets. It is evident that in systems $1\left(\mathrm{pH}_{\mathrm{i}} 10.85\right)$, the initial supersaturations expressed with respect to calcite were $S_{\mathrm{c}}=32.0$. The initial supersaturation in systems $2\left(\mathrm{pH}_{\mathrm{i}} 10.93\right)$ was even higher and was found to be, $S_{\mathrm{c}}=47.0$ (the initial supersaturation, expressed with respect to vaterite was, $S_{\mathrm{v}}=24.2$ ). Since in both systems the initial superstaturation was high, the precipitation expectedly started immediately after mixing the reactants, exhibiting a sudden drop of concentrations of the constituent ions (supersaturation). It should be mentioned that the systems 1 and 2 are supersaturated with respect to amorphous calcium carbonate. However, the increasing addition of GP caused the progressive lowering of the slope of progress curves, which indicated the inhibition of calcium carbonate precipitation. In addition to lowering the slope of progress curves, GP caused an apparent termination of precipitation (crystal growth) at different supersaturations: at higher GP concentration, the supersaturation at which no growth occurred was higher as well. ${ }^{*}$ In system 1 with GP concentration of 3 ppm and $6 \mathrm{ppm}$, this apparent termination of crystal growth at specific critical supersaturations, so-called "dead zone", was observed at $S_{\mathrm{c}} \approx 2.6$ and $S_{\mathrm{c}} \approx 6.1$, respectively. Any increase of GP concentration above $6 \mathrm{ppm}$ just slightly increased the $S_{\mathrm{c}}$ value and presumably not additionally influenced the growth kinetics and mechanism. According to the model of interactions between dissolved additives and growing crystal, proposed by Cabrera and Vermilyea, ${ }^{32}$ the appearance of the dead zone and termination of crystal growth in the solution still supersaturated with respect to the specific crystal phase, is assumed to be a consequence of the adsorption of GP molecules at the calcite crystal surfaces. On the other hand, in system 2 the "dead zone" plateau was not observed within the range of GP concentrations investigated. Since in this system calcite appeared in a mixture with vaterite, the observed inhibition of crystal growth is probably the result of GP interactions with crystals of both polymorphs.

In the ASW systems $\left(\mathrm{pH}_{\mathrm{i}} \approx 10.20\right)$ the initial supersaturation was, $S_{\mathrm{c}}=9.5$ (with respect to aragonite, $S_{\mathrm{a}}=8.0$ ). Since in this system magnesium ions, known as extremely strong inhibitors of calcium carbonate (particularly of calcite) precipitation, were present in concentrations 5.7 times higher than $\mathrm{Ca}^{2+}$ concentration, a long induction times were observed (control system:

\footnotetext{
* Actually, growth termination in the systems with different addition of GP is more pronounced at the respective $\mathrm{pH}$ versus time curves.
} 

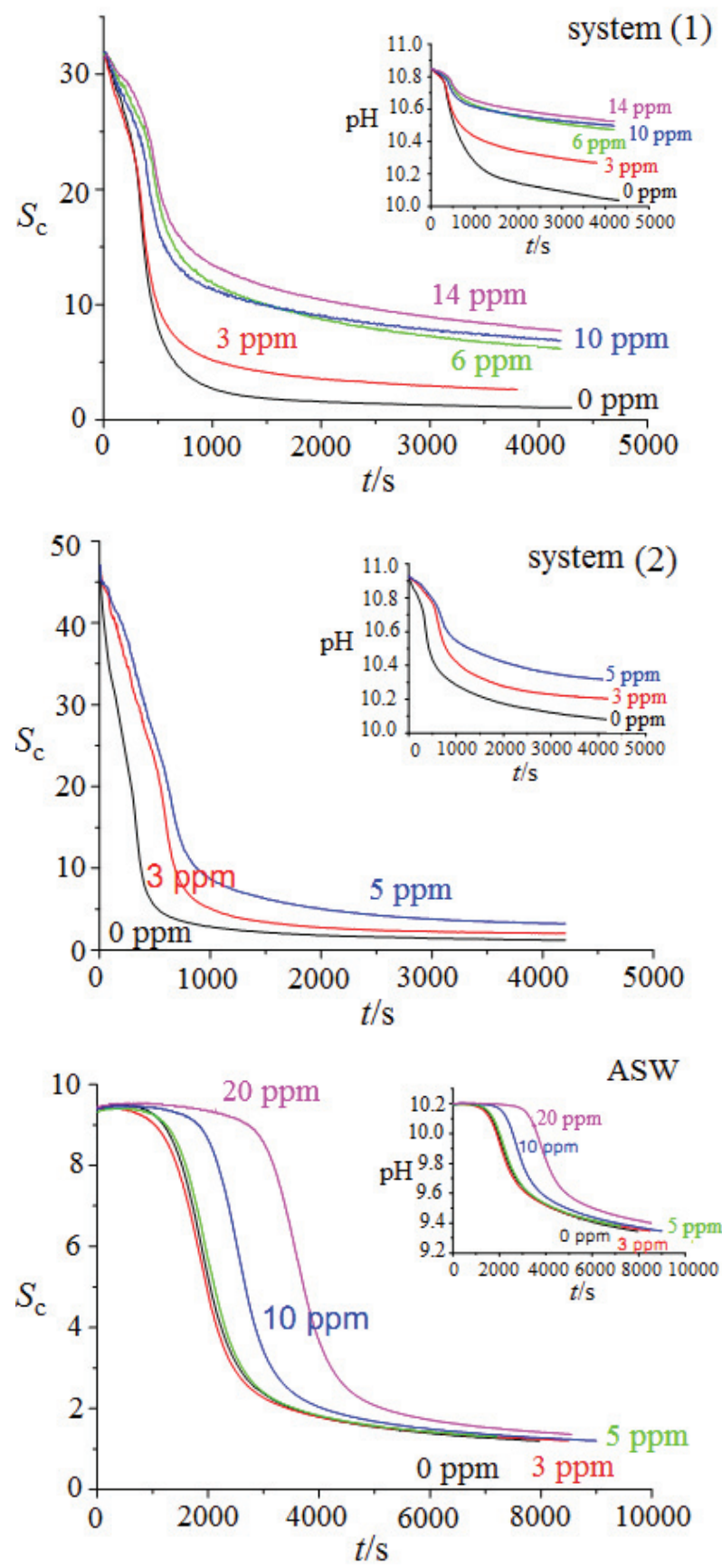

Figure 2. Progress curves, $S_{\mathrm{c}}$ versus time, of calcium carbonate precipitated in the systems of different initial supersaturations and composition: system 1: $c_{\mathrm{i}}\left(\mathrm{Ca}^{2+}\right)=$ $c_{\mathrm{i}}\left(\mathrm{CO}_{3}{ }^{2-}\right)=1.0 \times 10^{-2} \mathrm{~mol} \mathrm{dm}{ }^{-3}$, system 2: $c_{\mathrm{i}}\left(\mathrm{Ca}^{2+}\right)=$ $c_{\mathrm{i}}\left(\mathrm{CO}_{3}{ }^{2-}\right)=2.0 \times 10^{-2} \mathrm{~mol} \mathrm{dm}^{-3}$ and system 3 (artificial sea water, ASW). Concentrations of GP added into the systems are indicated.

$t_{\text {ind }} \approx 1500 \mathrm{~s}$ ). However, after the addition of increasing concentrations of GP, the induction times respectively increased, thus indicating the inhibition of the nucleation process.
Since the experimental results of the kinetics of precipitation in the presence of GP peptide demonstrated the overall retardation of nucleation (evident in the ASW system) and growth processes (more marked in the systems 1 and 2 than in ASW), the adsorption of GP on the growing calcium carbonate crystals (particularly calcite) seems to be a prevailing inhibition mechanism. Since the above data suggest an inhibition of crystal growth, due to the adsorption of GP onto the crystal surfaces, a change in the crystal sizes and morphologies is expected. Figure 3 shows low magnification scanning electron microscopy (SEM) micrographs of the crystals of spontaneously precipitated calcium carbonate polymorphs formed in systems 2, containing 0 ppm, 3.0 ppm or $10.0 \mathrm{ppm}$ of GP. In all these systems the precipitate consisted of calcite and vaterite, the former appeared as rhombohedral crystals, while the latter appeared as spherulites. $^{28,30,33}$ The vaterite particles are actually aggregates of primary crystallites of $25-35 \mathrm{~nm}$ in size. The size of primary crystallites was estimated earlier ${ }^{34}$ from the observed broadening of the diffraction lines of vaterite compared to calcite using the Scherrer equation. Figure 4 shows low magnification SEM micrographs of the crystals formed in systems 1 in which only calcite precipitated in the shape of rhombohedral crystals. Only in the presence of the highest concentrations of GP, some spherulitic vaterite crystallites have appeared. The crystals were about the same size within the whole range of GP concentrations investigated.

With these low magnification observations (Figures 3 and 4) it was not possible to observe the changes of crystal morphology caused by the presence of GP. However, the influence of GP on the crystal morphology was observed when high magnification SEM micrographs (Figure 5) were analyzed. They revealed textural differences between the crystals precipitated in the control system 1 and the GP containing systems 1 . In the control system the calcite crystals with well expressed, regular $\{104\}$ faces and edges were observed, while the crystals grown in the presence of 10 ppm GP expressed curved edges and new crystalline faces, different from the stable $\{104\}$ ones. The appearance of new faces is certainly the consequence of the adsorption of soluble green layer peptides, most probably through the carboxylate groups of their acidic residues (aspartic and glutamic acids) on crystalline planes exposing calcium ions. $^{27,35-41}$

As previously confirmed by mineralogical analysis, aragonite was the only calcium carbonate polymorph precipitated in the systems that mimic the composition of principle components of sea water. High magnification SEM micrographs (Figure 6) show that aragonite precipitated in a form of irregular aggregates of an average dimension of $2 \mu \mathrm{m}$. These crystals did not show the typical acicular morphology of synthetic 

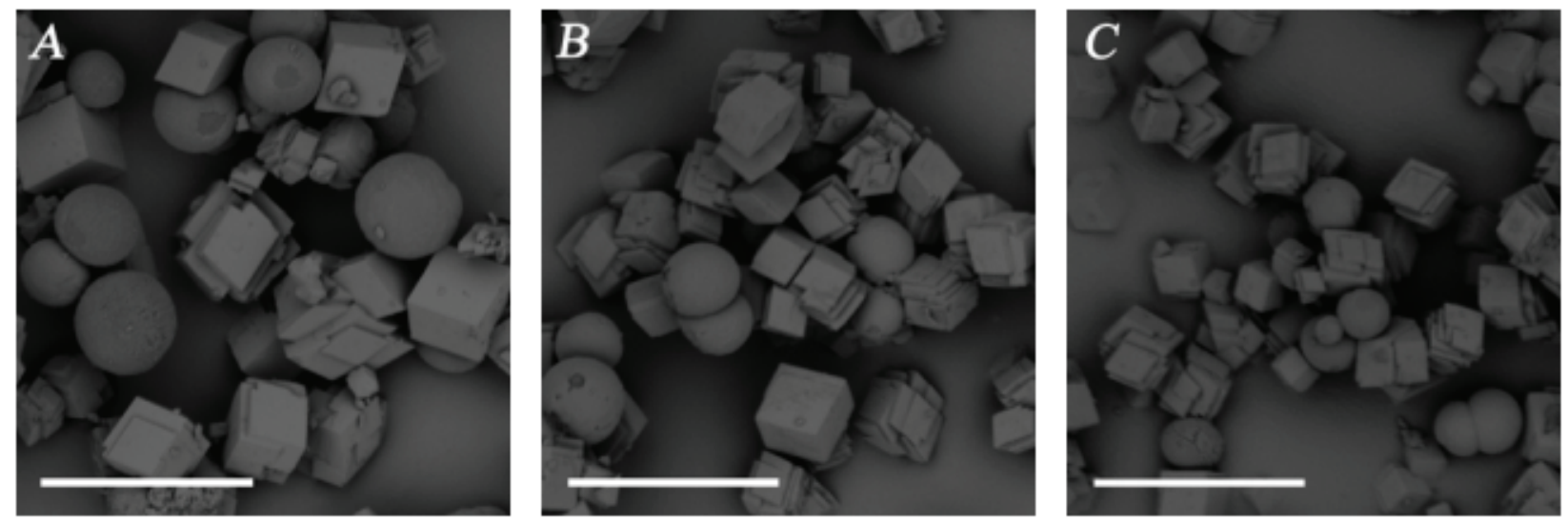

Figure 3. SEM micrographs of calcium carbonate samples isolated from the precipitation system 2: $c_{\mathrm{i}}\left(\mathrm{Ca}^{2+}\right)=c_{\mathrm{i}}\left(\mathrm{CO}_{3}{ }^{2-}\right)=$ $2.0 \times 10^{-2} \mathrm{~mol} \mathrm{dm}^{-3}$. The concentrations of green layer peptide added to the systems are: A) $\left.0 \mathrm{ppm}, \mathrm{B}\right) 3 \mathrm{ppm}$ and C) $10 \mathrm{ppm}$. Scale bar $40 \mu \mathrm{m}$.
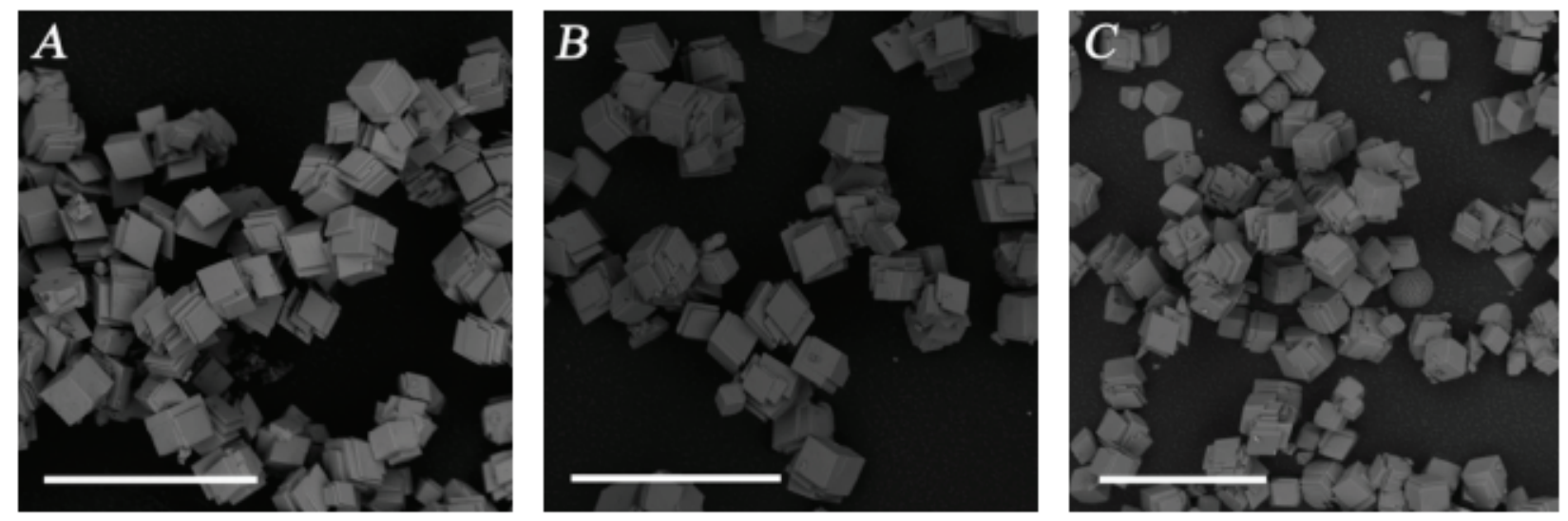

Figure 4. SEM micrographs of calcium carbonate samples isolated from the precipitation system 2: $c_{\mathrm{i}}\left(\mathrm{Ca}^{2+}\right)=c_{\mathrm{i}}\left(\mathrm{CO}_{3}{ }^{2-}\right)=$ $1.0 \times 10^{-2} \mathrm{~mol} \mathrm{dm}^{-3}$. The concentrations of green layer peptide added to the systems are: A) $\left.0 \mathrm{ppm}, \mathrm{B}\right) 3 \mathrm{ppm}$ and C) $10 \mathrm{ppm}$. Scale bar $40 \mu \mathrm{m}$.
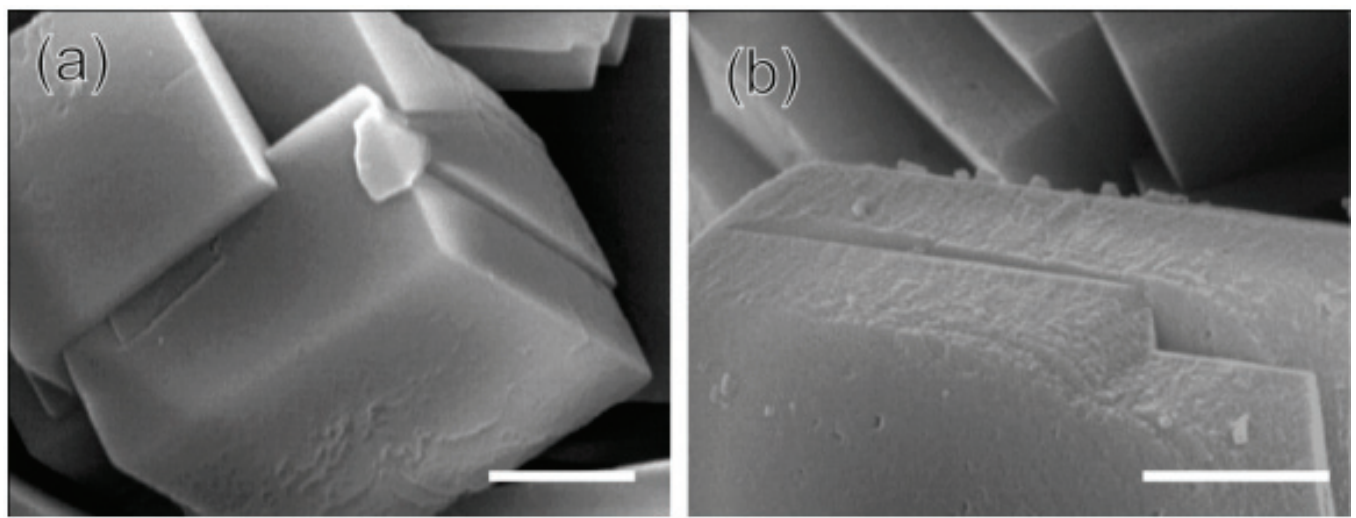

Figure 5. High magnification SEM micrographs of calcite samples isolated from the precipitation system $1: c_{\mathrm{i}}\left(\mathrm{Ca}^{2+}\right)=c_{\mathrm{i}}\left(\mathrm{CO}_{3}{ }^{2-}\right)=$ $1.0 \times 10^{-2} \mathrm{~mol} \mathrm{dm}^{-3}$. a) control system; b) $c(\mathrm{GP})=10 \mathrm{ppm}$. Scale bar $1 \mu \mathrm{m}$. 

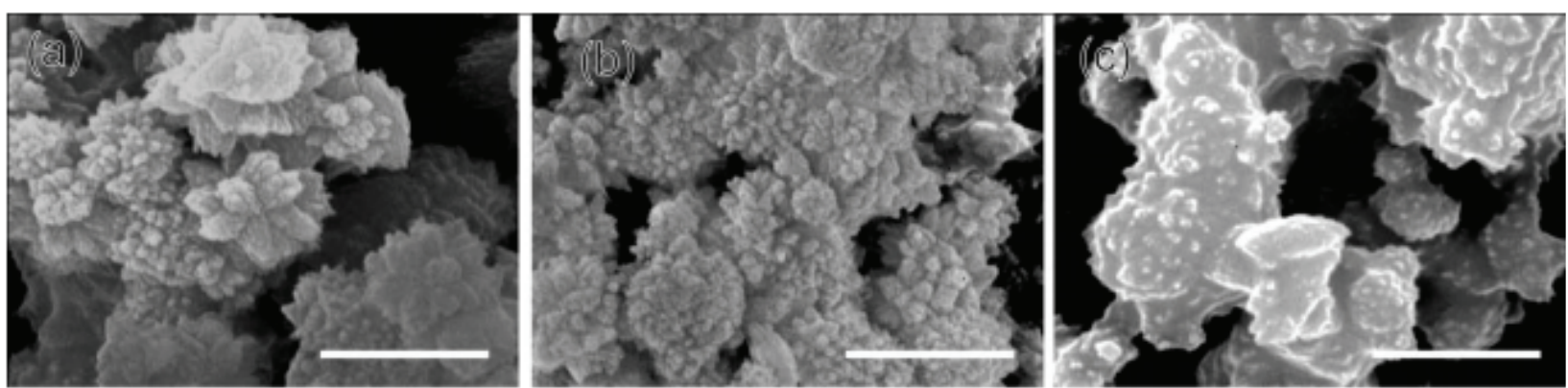

Figure 6. High magnification SEM micrographs of calcium carbonate samples isolated from the ASW precipitation system: $c_{\mathrm{i}}\left(\mathrm{Ca}^{2+}\right)=9.3 \times 10^{-3} \mathrm{~mol} \mathrm{dm}^{-3}, c_{\mathrm{i}}\left(\mathrm{CO}_{3}{ }^{2-}\right)=5.0 \times 10^{-3} \mathrm{~mol} \mathrm{dm}^{-3}$. The concentrations of green layer peptide added to the systems are: a) $0 \mathrm{ppm}$, b) $3 \mathrm{ppm}$ and c) $10 \mathrm{ppm}$. Scale bar $200 \mathrm{~nm}$.

aragonite. Only a few elongated needle-like crystals were observed. They appeared organized in radial way and emerging from a seeding crystallization point. The addition of GP did not change the average dimension of the aggregates. However, the progressive increase of the GP concentration, up to $10 \mathrm{ppm}$, caused a reduction of the size of acicular crystals and aragonite appeared more having a tablet-like structure. Just the minor changes in morphology, but still a disappearance of sharp edges and additional reduction of curving of the faces could be observed.

The results of precipitation kinetics and morphological observations of calcite and aragonite crystals, formed in the presence of soluble fraction of green organic sheets, pointed out to the interactions between dissolved macromolecules and mineral surfaces. ${ }^{42}$ However, calcite crystals interact with GP predominantly during the growth stage, while aragonite crystals predominantly during nucleation. Moreover GP seems to alter the morphology of aragonite crystals at larger

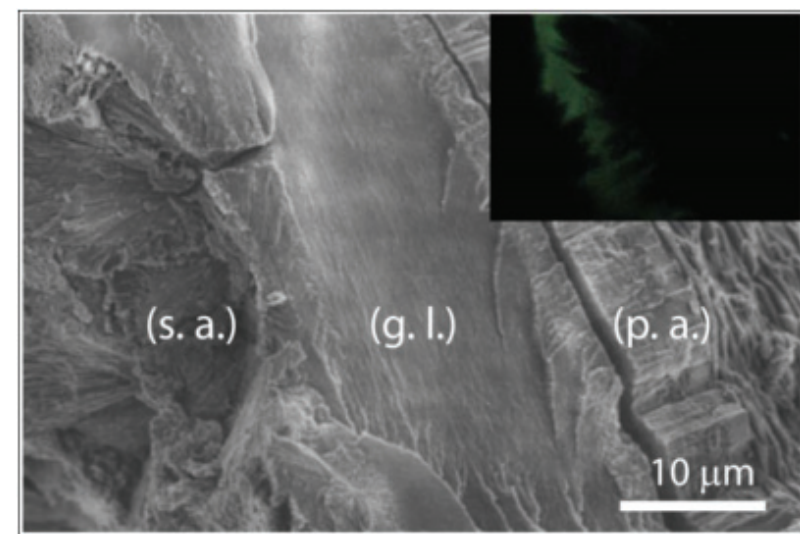

Figure 7. SEM micrographs of a fragment of abalone shell nacre, containing the green sheet. The layers of spherulitic aragonite (s. a.), green layer (g. 1.) and prismatic aragonite (p. a.) are indicated. The inset shows a fluorescent image $\left(\lambda_{\mathrm{ex}}=\right.$ $488 \mathrm{~nm}$ ) of a similar shell fragment in which a green fluorescence coincide with the green layer.
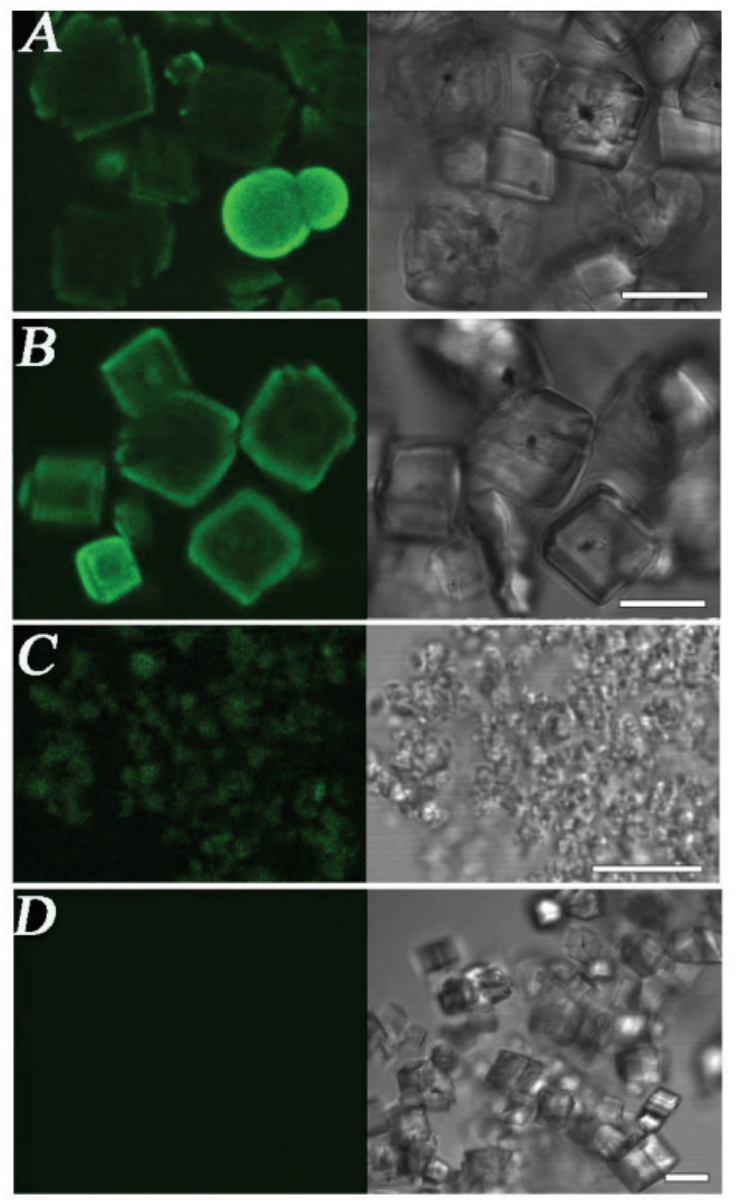

Figure 8. Confocal laser scanning microscopy of calcium carbonate crystals precipitated in: (A) system 2 $\left(c_{\mathrm{i}}\left(\mathrm{Ca}^{2+}\right)=c_{\mathrm{i}}\left(\mathrm{CO}_{3}{ }^{2-}\right)=2.0 \times 10^{-2} \mathrm{~mol} \mathrm{dm}^{-3}\right)$ in the presence of $10 \mathrm{ppm}$ GP, (B) system $1\left(c_{\mathrm{i}}\left(\mathrm{Ca}^{2+}\right)=c_{\mathrm{i}}\left(\mathrm{CO}_{3}{ }^{2-}\right)=\right.$ $\left.1.0 \times 10^{-2} \mathrm{~mol} \mathrm{dm}^{-3}\right)$ in the presence of $14 \mathrm{ppm} \mathrm{GP,} \mathrm{(C)}$ system ASW $\left(c_{\mathrm{i}}\left(\mathrm{Ca}^{2+}\right)=9.3 \times 10^{-3} \mathrm{~mol} \mathrm{dm}{ }^{-3}, c_{\mathrm{i}}\left(\mathrm{CO}_{3}{ }^{2-}\right)=\right.$ $\left.5.0 \times 10^{-3} \mathrm{~mol} \mathrm{dm}^{-3}\right)$ in the presence of $10 \mathrm{ppm} \mathrm{GP}$ and (D) system $1\left(c_{\mathrm{i}}\left(\mathrm{Ca}^{2+}\right)=c_{\mathrm{i}}\left(\mathrm{CO}_{3}{ }^{2-}\right)=1.0 \times 10^{-2} \mathrm{~mol} \mathrm{dm}^{-3}\right)$ without GP. Left - the fluorescence images, excitation at $\lambda_{\mathrm{ex}}=488 \mathrm{~nm}$ and detection at 500-590 nm; right - the images in the transmitted light. Scale bars: $10 \mu \mathrm{m}$ (A, B, C) and $20 \mu \mathrm{m}$ (D). 
extent than that of calcite crystals, so the aragonite crystals reduce their growth along the acicular axis and become more plate like. These findings of stronger interactions of GP with aragonite crystals than with calcite is of relevance in understanding the abalone biomineralization. In vivo the green organic sheets are actually interspersed through the nacre, thus demarcating the interruption of nacre synthesis and serve as a substrate for nucleation and the resumption of crystal growth. Prismatic and spherulitic aragonite phases precede and follow the deposition of the sheets as could be seen from the SEM micrograph of a section of abalone shell nacre (Figure 7).

In order to detect and observe a possible distribution of GP in the synthetic crystals as well, the confocal laser scanning microscopy was used to analyse the calcite, vaterite and aragonite crystals precipitated in the presence of GP. In agreement with the SEM observations, the rhombohedral calcite crystals and vaterite spherulites are observed in samples of system 2, predominantly calcite in system 1 and aragonite in ASW system. Figure 8 . shows that all polymorphs precipitated in the presence of GP exert a green fluorescence after excitation at $\lambda_{\mathrm{ex}}=488 \mathrm{~nm}$. However, both calcite and vaterite, display incorporation of GP predominantly in the surface and the intensity of the GP fluorescence is much stronger in the case of vaterite spherulites (Figure $8 \mathrm{~A})$. On the other hand, the calcite crystals formed in the precipitation system 1 (Figure $8 \mathrm{~B}$ ) have a significantly more intense fluorescent layer at their surface than the equivalent crystallites grown under conditions of system 2. Likely explanation for the observed differences in fluorescence intensity is related, not only to different concentrations of GP added to the respective systems, but also to significantly higher specific surface area of vaterite particles, that is, in turn, responsible for preferential adsorption of GP. The aragonite crystallites, precipitated in the ASW system containing $10 \mathrm{ppm}$ GP, are shown in Figure 8c in which weaker flourescence labeling (in comparisson to vaterite and calcite!) could be observed.

The crystals obtained in the appropriate control systems, grown in the absence of GP, show no fluorescent labeling. As an example, Figure $8 \mathrm{~d}$ shows the precipitate formed in system 1, without the addition of GP.

\section{CONCLUSION}

The effects of the interstitial green sheet polypeptide (GP), the protein fragment extracted from the green sheets interdispersed in the nacre of abalone shells, on the spontaneous precipitation of $\mathrm{CaCO}_{3}$ were investigated in three precipitation systems.

It was found that in the model systems, with no GP, different polymorphs of calcium carbonate precipi- tated. Thus, in system $1,\left(c_{\mathrm{i}}\left(\mathrm{Ca}^{2+}\right)=c_{\mathrm{i}}\left(\mathrm{CO}_{3}{ }^{2-}\right)=\right.$ $\left.1.0 \times 10^{-2} \mathrm{~mol} \mathrm{dm}^{-3}\right)$ the initial precipitate consisted entirely of calcite, while in system $2,\left(c_{\mathrm{i}}\left(\mathrm{Ca}^{2+}\right)=\right.$ $\left.c_{\mathrm{i}}\left(\mathrm{CO}_{3}{ }^{2-}\right)=2.0 \times 10^{-2} \mathrm{~mol} \mathrm{dm}^{-3}\right)$ a mixture of vaterite and calcite was formed. In system 3 (ASW, artificial sea water) only aragonite precipitated.

The mineralogical composition of the precipitates, isolated from the systems into which GP was added, showed no significant difference from the respective control systems, regardless the GP concentrations used.

The results also show that GP is able to control the precipitation of calcium carbonate by its adsorption on the crystal surfaces and entrapment into the mineral structure thus modifying their morphology. The adsorption of GP at all three polymorphs, vaterite, calcite and aragonite, was additionally corroborated by the confocal laser scanning microscopy.

Acknowledgements. The financial support from the Ministry of Science, Education and Sports of the Republic of Croatia (project No. 098-0982904-2951) is gratefully acknowledged.

\section{REFERENCES}

1. H. A. Lowenstam and S. Weiner, On Biomineralization, Oxford University Press, New York, 1989.

2. P. M. Dove, J. J. De Yoreo, and S. Weiner, Biomineralization, Mineralogical Society of America, Washington, DC, 2003.

3. S. Weiner, J. Mahamid, Y. Politi, Y. Ma, and L. Addadi, Front Mater. Sci. China 3 (2009) 104-108.

4. S. Mann, Angew. Chem., Int. Ed. 39 (2000) 3392-3406.

5. L. Addadi, D. Joester, F. Nudelman, and S. Weiner, Chem.-Eur. J. 12 (2006) 981-987.

6. F. C. Meldrum and H. Colfen, Chem. Rev. 108 (2008) 4332-4432.

7. F. Nudelman and N. A. J. M. Sommerdijk, Angew. Chem. Int. Ed. 51 (2012) 6582-6596.

8. S. Weiner, I. Sagi, and L. Addadi, Science 309 (2005) 1027-1028.

9. A. Neira-Carrillo, D. F. Acevedo, M. C. Miras, C. A. Barbero, D. Gebauer, H. Cölfen, and J. L. Arias, Langmuir 24 (2008) 12496-12507.

10. D. Gebauer, A. Völkel, and H. Cölfen, Science 322 (2008) 1819-1822.

11. E. M. Pouget, P. H. H. Bomans, J. A. C. M. Goos, P. M. Frederik, G. De With, and N. A. J. M. Sommerdijk, Science $\mathbf{3 2 3}$ (2009) 1455-1458.

12. I. M. Weiss, N. Tuross, L. Addadi, and S. Weiner, J. Exp. Zool. 293 (2002) 478-491.

13. J. C. Marxen, W. Becker, D. Finke, B. Hesse, and M. Epple, J. Molluscan Stud. 69 (2003) 113-121.

14. A. Sugawara, T. Nishimura, Y. Yamamoto, H. Inoue, H. Nagasawa, and T. Kato, Angew. Chem., Int. Ed. 45 (2006) 2876-2879.

15. Y. Politi, Y. Levi-Kalisman, S. Raz, F. Wilt, L. Addadi, S. Weiner, and I. Sagi, Adv. Funct. Mater. 16 (2006) 1289-1298.

16. B. Hasse, H. Ehrenberg, J. C. Marxen, W. Becker, and M. Epple, Chem. Eur. J. 6 (2000) 3679-3685.

17. L. Addadi, J. Moradian, E. Shay, N. G. Maroudas, and S. Weiner, Proc. Natl. Acad. Sci. USA 84 (1987) 2732-2736.

18. F. Nudelman, B. A. Gotliv, L. Addadi, and S. Weiner, J. Struct. Biol. 153 (2006) 176-187. 
19. C. Du, G. Falini, S. Fermani, C. Abbott, and J. Moradian-Oldak, Science 307 (2005) 1450-1454.

20. J. Erasmus, P. A. Cook, and N. Sweijd, J. Shellfish Res. 13 (1994) 493-501.

21. X. Su, A. M. Belcher, C. M. Zaremba, D. E. Morse, G. D. Stucky, and A. H. Heuer, Chem. Mater. 14 (2002) 3106-3117.

22. A. M. Belcher, X. H. Wu, R. J. Christensen, P. K. Hansma, G. D. Stucky, and D. E. Morse, Nature 381 (1996) 56-58.

23. G. Falini, G. Sator, D. Fabri, P. Vergni, S. Fermani, A. M. Belcher, G. D. Stucky, and D. E. Morse, J. Struct. Biol. 173 (2011) 128-137.

24. S. L. Tracy, C. J. P. Francois, and H. M. Jennings, J. Cryst. Growth 193 (1993) 374-381.

25. D. Kralj, Lj. Brečević, and A. E. Nielsen, J. Cryst. Growth 104 (1990) 793-800.

26. Powder diffraction file, inorganic volume, Table Nos. 01-0721937 for calcite; 00-005-0453 for aragonite; 01-72-0506, for vaterite, International Centre for Diffraction data, Swarthmore, PA, USA.

27. B. Njegić-Džakula, Lj. Brečević, G. Falini, and D. Kralj, Cryst. Growth Des. 9 (2009) 2425-2434.

28. D. Kralj, Lj. Brečević, and A. E. Nielsen, J. Cryst. Growth 143 (1994) 269-276.

29. D. Kralj and Lj. Brečević, Colloids Surf. 96 (1995) 287-293.

30. D. Kralj, Lj. Brečević, and J. Kontrec, J. Cryst. Growth 177 (1997) 248-257.
31. L. N. Plummer and E. Busenberg, Geochim. Cosmochim. Acta 46 (1982) 1011-1040.

32. N. Cabrera and D. A. Vermilyea, in: R. H. Doremus, B. W. Roberts, and D. Turnbull (Eds.), Growth and Perfection of Crystals, Wiley, New York, 1958.

33. Lj. Brečević and D. Kralj, Croat. Chem. Acta 80 (2007) 467-484.

34. Lj. Brečević, V. Nöthig-Laslo, D. Kralj, and S. Popović, J. Chem. Soc., Faraday Trans. 92 (1996) 1017-1022.

35. B. Njegić-Džakula, G. Falini, Lj. Brečević, Ž. Skoko and D. Kralj, J. Colloid Interface Sci. 343 (2010) 553-563.

36. F. Manoli and E. Dalas, J. Cryst. Growth 222 (2001) 293-297.

37. F. Manoli, J. Kanakis, P. Malakaj, and E. Dalas, J. Cryst. Growth 236 (2002) 363-370.

38. H. Tong, W. T. Ma, L. L. Wang, P. Wan, J. M. Hu, and L. X. Cao, Biomaterials 25 (2004) 3923-3929.

39. D. Volkmer, M. Fricke, T. Huber, and N. Sewald, Chem. Commun. (2004) 1872-1873.

40. A. J. Xie, Y. H. Shen, C. Y. Zhang, Z. W. Yuan, X. M. Zhu, and Y. M. Yang, J. Cryst. Growth 285 (2005) 436-443.

41. H. Cölfen, Curr. Opin. Colloid Interface Sci. 8 (2003) 23-31.

42. A. Adamiano, S. Bonacchi, N. Calonghi, D. Fabbri, G. Falini, S. Fermani, D. Genovese, D. Kralj, M. Montalti, B. NjegićDžakula, L. Prodi, and G. Sartor, Chem. Eur. J. 18(2012), 14367-14374. 